http://doi.org/10.11646/zootaxa.4189.1.4

http://zoobank.org/urn:lsid:zoobank.org:pub:E65837C7-40B5-497E-B435-BE3113FC6DF6

\title{
An update on the genus Longidorus, Paralongidorus and Xiphinema (Family Longidoridae) in Portugal
}

\author{
CARLOS GUTIÉRREZ-GUTIÉRREZ ${ }^{1,4}$, MARIA ANTONIA BRAVO², MARGARIDA TEIXEIRA SANTOS², \\ PAULO VIEIRA $^{1} \&$ MANUEL MOTA ${ }^{1,3}$ \\ ${ }^{1}$ NemaLab/ICAAM, Instituto de Ciências Agrárias e Ambientais Mediterrânicas \& Dept. de Biologia, Universidade de Évora, Núcleo \\ da Mitra, Ap. 94, 7002-554 Évora, Portugal \\ ${ }^{2}$ Instituto Nacional de Investigação Agrária e Veterinária (INIAV), Quinta do Marquês, 2780-159 Oeiras, Portugal \\ ${ }^{3}$ Dept. Ciências da Vida, Universidade Lusófona de Humanidades e Tecnologias, EPCV, C. Grande 376, 1749-024 Lisboa, Portugal \\ ${ }^{4}$ Corresponding author. E-mail: carlosg@uevora.pt
}

\begin{abstract}
The tribe Longidorini within the subfamily Longidorinae (Longidorus spp. and Paralongidorus spp.) and the subfamily Xiphineminae (Xiphinema spp.) are two large nematode groups with about 260 and 230 known species, respectively. They are globally two important groups of ectoparasitic nematodes considered to be major pests because of their activity as vectors of important plant nepovirus, with some species included in the list of quarantine pathogenic organisms in many European countries. Knowledge of the biodiversity and occurrence of this nematode group is a prerequisite for the establishment of sound management strategies and control measures. According to data collected from the databases (such as EPPO, FSTA, and Web of Science) and published in specialised literature, a total of 15 Longidorus, 1 Paralongidorus and 40 Xiphinema species have been recorded as present in Portugal. However, the taxonomic status of some species is controversial, and thus needs to be clarified. A comprehensive review for unravelling the biodiversity and occurrence of nematode species of the genus Longidorus, Paralongidorus and Xiphinema in Portugal is herein provided. This review includes an updated checklist of species with information on the localities, host plants and geographical distribution. Additionally, maps on the species distributions of Longidorinae and Xiphineminae nematodes present in Continental Portugal and the Portuguese Macaronesian islands are provided, as well as unpublished data on authors and comments on the current taxonomic status. Finally, new insights and directions for future research on Longidoridae in Portugal are presented.
\end{abstract}

Key words: biodiversity, identification, longidorid, Longidorinae, occurrence, taxonomy, Xiphineminae

\section{Introduction}

The family Longidoridae Thorne, 1935, includes the genera Longidorus Micoletzky, 1922, Paralongidorus Siddiqi, Hooper \& Klan, 1963 (superfamily Longidorinae), and Xiphinema Cobb, 1913 (superfamily Xiphineminae) (Decraemer \& Robbins 2007). These migratory ectoparasitic nematodes, commonly known as longidorid nematodes, are characterized by a large body (length between 1.5-12.0 mm) and a long stylet (length between 80-290 um). They comprise a group of phytopathogenic species that damage a wide range of wild and cultivated plants through direct feeding on root cells and transmission of several plant pathogenic viruses (Taylor \& Brown 1997; Decraemer \& Robbins 2007; Decraemer \& Chaves 2012). Longidorus, Paralongidorus and Xiphinema are the three largest of the virus vector nematode genera with about 160, 70 and 260 known species, respectively (Decraemer \& Chaves 2012; Archidona-Yuste et al. 2016a, b; Esmaeili et al. 2016), but only some species (8, 1 and 9, respectively) have been shown to transmit nepoviruses (Taylor \& Brown 1997; Decraemer \& Robbins 2007; Decraemer \& Chaves 2012). To date only five known virus vector nematodes species from Longidoridae have been reported to be implicated in plant virus transmission in Portugal: Xiphinema index Thorne \& Allen, 1950, X. diversicaudatum (Micoletzky, 1927) Thorne, 1939, X. rivesi Dalmasso, 1969, Longidorus macrosoma Hooper, 1961, and Paralongidorus maximus (Bütschli, 1874) Siddiqi, 1964 (Bravo \& Lemos 1997; 
Taylor \& Brown 1997) (Table S1). In addition, some Longidoridae nematode species are included in the list of quarantine organisms of the European and Mediterranean Plant Protection Organization (EPPO). Xiphinema index is one of the most significant plant parasitic nematodes (Jones et al. 2013) because it is the vector nematode of Grapevine fanleaf virus (GFLV), one of the most destructive viral diseases affecting grapevine (Andret-Link et al. 2004). Taxonomic studies on both Longidorinea and Xiphineminae nematodes, including identification of species, enable us to catalogue and explain the biodiversity of these groups, which is important because of their implications in the natural ecological processes in the soil as well as pest management and the establishing of phytosanitary measures. Historically, nematologists have relied only on morphological and morphometric characters to identify species within the subfamily Longidorinae and Xiphineminae (Lamberti et al. 2000; Coomans et al. 2001; Decraemer \& Chaves 2012). They are characterized by a greatly conserved morphology, with similar anatomical characteristics and high inter- and intra-specific morphometric variability, making species delimitation a very complex and time-consuming task (Coomans et al. 2001; Decraemer \& Chaves 2012). Also, the large number of anatomical similarities within these taxonomic groups make it difficult to agree on the number of valid species (Lamberti et al. 2000; Coomans et al. 2001; Decraemer \& Chaves 2012). In fact, the use of polytomous keys is recommended for identification at species level (Brown \& Halbrendt 1997; Chen et al. 1997; Escuer \& Arias 1997; Lamberti et al. 2000). Despite this, the taxonomy within the genus Longidorus, Paralongidorus and Xiphinema is controversial, with a large number of putative species continuously being the subject of debate (Decraemer \& Chaves 2012; Archidona-Yuste et al. 2016a, b; Esmaeili et al. 2016). Currently, molecular techniques are used as supplementary tools to help in the differentiation at species level (GutiérrezGutiérrez et al. 2012, 2013a,b; Tzortzakakis et al. 2014; Esmaeili et al. 2016; Handoo et al. 2016). An integrative approach based upon the combination of classical morphological taxonomy and molecular barcoding of ribosomal DNA (rDNA) and mitochondrial DNA (mtDNA) genes is a useful strategy for identification at species level within the family Longidoridae. In addition the identification of DNA fragments has the potential of being used as species-specific molecular markers (Gutiérrez-Gutiérrez et al. 2013a, b; Chizhov et al. 2014; Tzortzakakis et al. 2014; Subbotin et al. 2014; Archidona-Yuste et al. 2016a; Lazarova et al. 2016).

The discovery of the transmission of GFLV by $X$. index (Hewitt et al. 1958) and subsequent studies in Portugal (Sequeira \& Dias 1964) stimulated interest on the virus vector nematodes and their associated viruses as well as the interactions within different crops (Brown \& Taylor 1987; Bravo \& Lemos 1997; Brown \& Trudgill 1997; Taylor \& Brown 1997). Therefore, these plant nematode groups have been recorded throughout the last six decades (Table S1), starting with the works of Lima (Lima 1962, 1965). Unfortunately, this research area has not been studied during the past fifteen years in Portugal, and lacks updated information on the current biodiversity and distribution patterns of these nematodes. In addition, the taxonomic status of some Longidoridae nematodes reported in Portugal is currently considered to be controversial, with some cases of putative species with dubious identifications and other species currently considered to be synonymous and needing re-evaluation.

To date, in Portugal, most of the taxonomic studies on the Longidorinae and Xiphineminae nematodes has been based on morphological and morphometric analysis (Brown \& Taylor 1987; Bravo \& Lemos 1997; Taylor \& Brown 1997; Peña-Santiago et al. 2006) (Table S1), and there is little molecular data on longidorid species (He et al. 2005; Molinari et al. 1997, 2006; Lazarova et al. 2006; Chizhov et al. 2014). Most nematode species belonging to the genera Longidorus, Paralongidorus and Xiphinema are often found infesting a wide range of forest and cultivated plants in Portugal (Table S1); however, most of them are associated with fruit tree plantations and vineyards (18 Xiphinema spp. and 6 Longidorus spp.) (Table S1). In Portugal, the biodiversity of these species was reviewed almost 20 years ago (Bravo \& Lemos 1997). A large number of reports with new records and descriptions of species have been published (Bravo \& Roca 1995, 1998; Roca \& Bravo 1996, 1997, 1998; Bravo et al. 2001; Gutiérrez-Gutiérrez et al. 2015), increasing the number of species occurring in Portugal to a total of 56 (Figures 15; Table S1). An inventory of soil and freshwater nematodes from the Iberian Peninsula was published by PeñaSantiago et al. (2006) and the diversity of nematode species in the Macaronesian region was reviewed in detail by Vieira et al. (2008) and Borges (2010). Several comparatives studies on the biodiversity and biogeophaphic distribution of species belong to the genus Longidorus, Paralongidorus and Xiphinema in the Mediterranean Basin and Central Europe (Navas et al. 1990, 1993) and worldwide (Coomans et al. 2001) was reported. In general, the biodiversity of plant nematodes of Longidoridae in the Iberian Peninsula appears to be one of the highest in the world (Taylor \& Brown 1997; Coomans et al. 2001; Peña-Santiago et al. 2006; Archidona-Yuste et al. 2016a, b), although it appears to be higher in Xiphineminae than in Longidorinae (Bravo \& Lemos 1997; Peña-Santiago et al. 
2006). Many of them are considered as to be species endemic to the Iberian Peninsula (Table S1) and GutiérrezGutiérrez et al. (2011) hypothesized that the Iberian Peninsula could be considered as a possible centre of origin for some Xiphinema species because of the high number of endemic species and their phylogenetic grouping.

The aim of this comprehensive review is to clarify the biodiversity, and taxonomic positions of species belonging to the genera Longidorus, Paralongidorus and Xiphinema from the family Longidoridae present in Portugal. Information from databases, specialised literature and unpublished data of the authors is provided. An updated checklist of species with notes on the taxonomic status and maps of the diversity and the geographical distribution of species in Portugal is presented. Insights and directions for future research on plant nematodes of Longidoridae in Portugal are also presented.

\section{Family Longidoridae in Portugal}

\section{Genus Xiphinema}

\section{Xiphinema species are members of the $X$. americanum-group}

To our knowledge, the first reference on Xiphinema spp. occurring in Portugal dates from 1962 (Lima 1962, 1965). Lima studied in depth a complex of Xiphinema species closely related morphologically, which currently comprise the X. americanum-group (Lamberti \& Bleve-Zacheo 1979). Lima (1968) and Tarjan (1969) were the first researchers to argue that $X$. americanum Cobb, 1913, was not a single species but a species complex containing several species; later this idea of a species complex was strengthened (Lamberti \& Bleve-Zacheo 1979). Currently more than 55 valid species are included within this species complex, with some species transmitting important American nepovirus, one of which is $X$. americanum sensu stricto (s.s.) (Lamberti et al. 2000; Archidona-Yuste et al. 2016a). The application of molecular techniques to supplement taxonomic and systematics studies on the genus Xiphinema particularly in the X. americanum group has revealed that within the X. americanum-group some longassumed single species are in fact cryptic (i.e. genetically distinct but morphologically almost indistinguishable) (Barsi \& De Luca 2008; Oliveira et al. 2005, 2006; Archidona-Yuste et al. 2016a; Lazarova et al. 2016). Unfortunately, only a small number of Portuguese populations of this taxonomic group have been molecularly characterized (He et al. 2005; Molinari et al. 1997, 2006; Lazarova et al. 2006) and, as a result, the taxonomic status of some species of the X. americanum-group reported in Portugal has been contentious. To date a total of 15 Xiphinema species have been reported to occur in Portugal belonging to the X. americanum-group (Figures 1, 4, 5; Table S1), most of them being Iberian endemics. In general, this group is characterized morphologically by a short body length $(<3 \mathrm{~mm}), \mathrm{V}$ (vulva) localized around or behind the middle of the body, and a female reproductive system with two short equally developed genital branches, with short and simplified uteri without uterine differentiation (Lamberti et al. 2000; Decraemer \& Chaves 2012). Based on hierarchical cluster analysis (HCA) of morphometric data, the Portuguese populations of $X$. americanum group species are grouped in three subgroups: the $X$. americanum-subgroup, the $X$. pachtaicum-subgroup, and the $X$. pachydermum-subgroup that included $X$. pachydermum Sturhan, 1983, and others Portuguese $X$. americanum-group species closely related to $X$. pachydermum (Lamberti et al. 1993; Lamberti \& Ciancio 1993; Coomans et al. 2001). The taxonomic status and validity of some species of these subgroups described in Portugal has been questioned.

\section{Xiphinema americanum-subgroup species}

A large number of populations belonging to species of the $X$. americanum-subgroup have been reported, including a population from the south-west of Portugal (Setúbal) originally identified firstly as $X$. americanum, and later proposed as X. brevicolle Lordello \& Da Costa, 1961 (Lima 1968; Luc et al. 1998; Lamberti \& Bleve-Zacheo 1979) (Figure 1). Sturhan (1973) also reported several populations of this same species in the Azores Islands (S. Miguel, Terceira, S. Jorge, and Faial) (Figure 5; Table S1). Two species closely related morphologically to $X$. brevicolle were identified as X. incognitum Lamberti \& Bleve-Zacheo, 1979, and X. diffusum Lamberti \& BleveZacheo, 1979, both species being reported from Madeira Island (Bravo 1989; Lamberti et al. 1994) (Table S1). Additionally the second species was also reported in a locality of the west-central continental region (Quinta do 
Hilário, Setúbal) (Figure 1; Table S1). However, some authors regard both $X$. incognitum and X. diffusum to be synonymous with $X$. brevicolle (Luc et al. 1998; Coomans et al. 2001). Xiphinema rivesi Dalmasso, 1969, and X. santos Lamberti, Lemos, Agostinelli \& D'Addabbo, 1993 have been reported in Portugal (Lamberti et al. 1993, 1994; Bravo \& Lemos 1997) (Figures 1, 4, 5; Table S1) and other Mediterranean regions (Lamberti et al. 1996, 2000; Taylor \& Brown 1997; Decraemer \& Chaves 2012); however, only the first species is widespread (Lamberti et al. 2000, 2004; Coomans et al. 2001; Decraemer \& Robbins 2007). Both species belong to the X. americanumsubgroup and appear to be morphologically almost identical, but the Iberian populations of both species are clearly separated phylogenetically using molecular ribosomal markers (Gutiérrez-Gutiérrez et al. 2011; Archidona-Yuste et al. 2016a). Xiphinema rivesi is a vector of several important nepovirus (Taylor \& Brown 1997; Decraemer \& Chaves 2012) but in Portugal its presence has never been associated with viral diseases in plants. Xiphinema santos was described the first time by Lamberti et al. (1993) from several populations infesting vineyards localized in the Dão wine region and subsequently reported extensively in the continental region as well as Madeira and Azores (Terceira) islands associated with many species of plants (Figures 1, 4, 5; Table S1). Several Macaronesian populations of $X$. santos had previously been identified as X. intermedium Lamberti \& Bleve-Zacheo, 1979 (Bravo 1983; Bravo \& Lemos 1997).

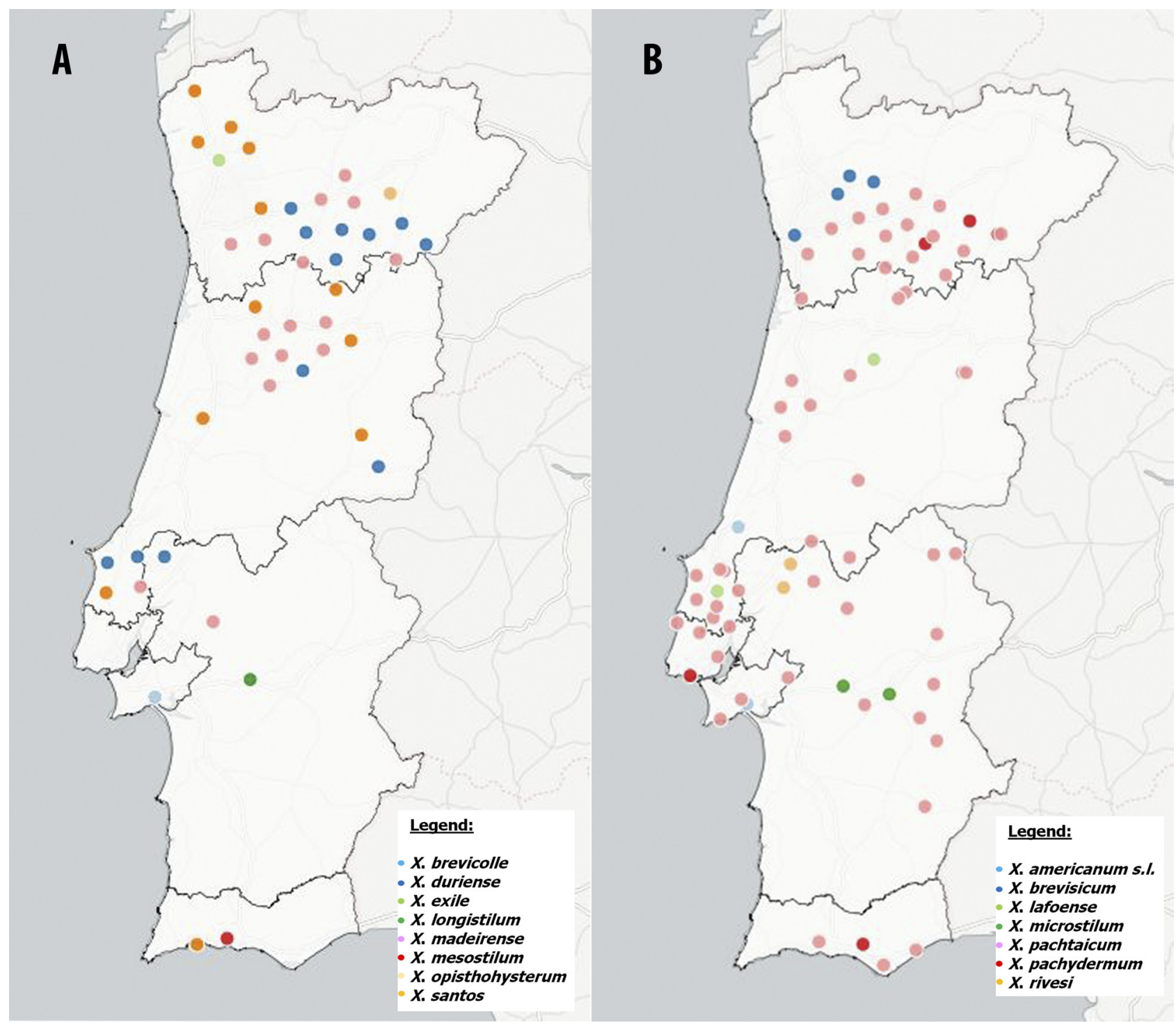

FIGURE 1. Geographic distribution of populations from $X$. americanum group species in Continental Portugal: (A) Xiphinema brevicolle, $X$. duriense, X. exile, X. longistilum, X. madeirense, X. mesostilum and X. santos; (B) X. americanum sensu lato (s.l.), X. brevisicum, X. lafoense, X. microstilum, X. pachtaicum, X. pachydermum and X. rivesi. This map may be similar but not identical to other published maps of Portugal designed using the mapping software Cartodb. This map is for illustrative purposes only. 

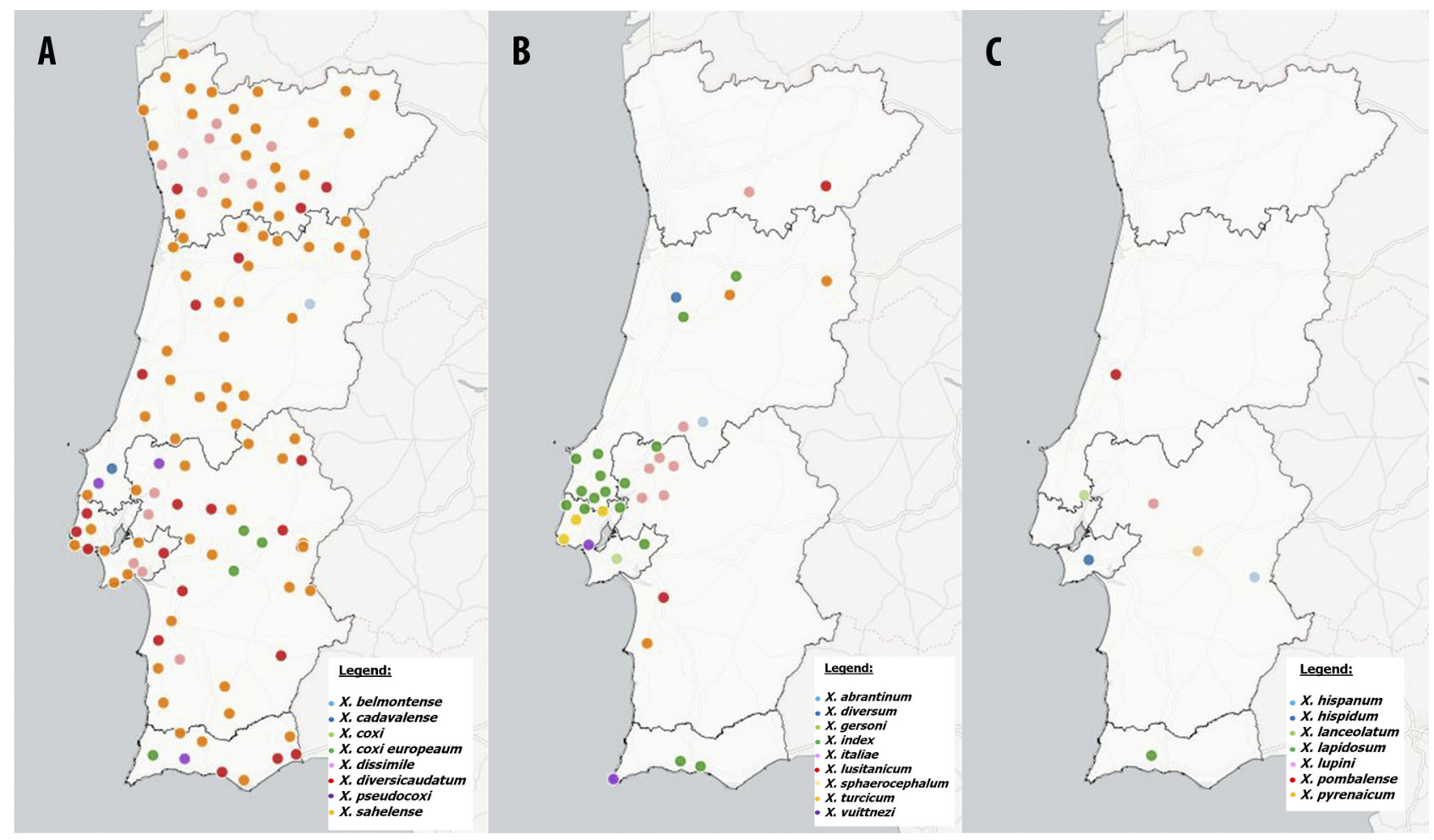

FIGURE 2. Geographic distribution of populations from Xiphinema spp. in Continental Portugal: (A) Xiphinema belmontense, $X$. cadavalense, X. coxi, X. coxi europaeum, X. dissimile, X. diversicaudatum and X. pseudocoxi; (B) X. abrantinum, X. diversum, X. gersoni, X. index, X. vuittenezi, X. italiae, X. lusitanicum, X. sphaerocephalum and X. turcicum; (C) X. hispanum, $X$. hispidum, X. lanceolatum, X. lapidosum, X. lupini, X. pombalense and X. pyrenaicum. This map may be similar but not identical to other published maps of Portugal designed using the mapping software Cartodb. This map is for illustrative purposes only.

\section{Xiphinema pachtaicum-subgroup species}

Xiphinema pachtaicum (Tulaganov 1938) Kirjanova, 1951, and X. madeirense Brown, Faria, Lamberti, Halbrendt, Agostinelli \& Jones, 1993, belong to the X. pachtaicum-subgroup and they have been both reported in Portugal (Figures 1, 4, 5; Table S1). Xiphinema pachtaicum is widespread in the Mediterranean region (Brown \& Taylor 1987; Bravo \& Lemos 1997; Taylor \& Brown 1997; Lamberti et al. 2000; Getaneh et al. 2015; Archidona-Yuste et al. 2016a), whilst the geographical distribution of $X$. madeirense is restricted to Portugal and Spain (ArchidonaYuste et al. 2016a). Xiphinema pachtaicum was cited in Portugal for the first time by Lima $(1962,1965)$ and since then a large number of authors have reported this species both in the continental region and the overseas territories including the islands of Madeira and Azores (Azores, Pico, Terceira, S. Miguel and S. Jorge) (Figures 1, 4, 5; Table S1). Xiphinema madeirense was described from specimens collected from the rhizosphere of the "Laurisilva" forest (Laurus nobilis L.) at Queimadas, Santana (Madeira island); however it has also been reported infesting vineyard soils in the North and Central continental regions and in the Azores islands (Figures 1, 4, 5; Table S1).

\section{Xiphinema pachydermum-subgroup species}

The $X$. pachydermum-subgroup is a particular group within the $X$. americanum-group since it is mainly composed of Spanish and Portuguese species characterized by $i$ ) frequent males; ii) females that do not show symbiotic bacteria associated with the ovaries (except in X. mesostilum); and iii) an oviduct clearly separated from the uterus by a well-developed sphincter muscle and longer uteri (Luc et al. 1998; Decraemer \& Geraert 2013; ArchidonaYuste et al. 2016a). Some researchers proposed X. pachydermum-subgroup as a group outside the X. americanumgroup (Coomans et al. 2001; He et al. 2005; Gutiérrez-Gutiérrez et al.2012a). A total of nine species belonging to 
the X.pachydermum-subgroup has been reported in Portugal, included X. brevisicum Lamberti, Bravo, Agostinelli \& Lemos, X. duriense Lamberti, Lemos, Agostinelli \& d' Addabo, 1993, X. exile Roca, Lamberti, Santos \& Abrantes, 1989, X. lafoense Roca, Pereira \& Lamberti, 1987, X. longistilum Lamberti, Bravo, Agostinelli \& Lemos, 1994, X. mesostilum Lamberti, Bravo, Agostinelli \& Lemos, 1994, X. microstilum Lamberti, Bravo, Agostinelli \& Lemos, 1994, X. opisthohysterum Siddiqi, 1961, and X. pachydermum (Figures 1, 4, 5; Table S1). Sturhan reported for the first time $X$. opisthohysterum and in 1983 described a new species named $X$. pachydermum, which morphologically resembles $X$. pachtaicum and was found in soil from a farm at Torre de Moncorvo (province of Trás-os-Montes) (Sturhan 1983; Bravo \& Lemos 1997). Since then X. pachydermum has been reported extensively in the North of Portugal and has also been reported in the Estremadura and Algarve regions (Lamberti et al. 1993, 1994; Bravo \& Lemos 1997) (Figure 1; Table S1). Two new endemic species, $X$. exile and X. lafoense, were described by Roca et al. (1987, 1989a). Lamberti et al. (1993, 1994) established the occurrence of $X$. americanum-group species in the main grapevine-growing regions of Portugal. Detailed morphometric and morphological studies enabled species discrimination in this group, which is characterized by high morphological similarity and overlapping morphometrics, resulting in the description of five species namely $X$. brevisicum, $X$. duriense, $X$. longistilum, $X$. mesostilum and X. microstilum. These authors hypothesized that the population described by Sturhan in 1983 as $X$. opisthohysterum was probably $X$. duriense because of their similar morphology and different geographical localities. Subsequently, Gutiérrez-Gutiérrez et al. (2012) and ArchidonaYuste et al. (2016a) carried out morphological and molecular studies to establish the species composition of the $X$. americanum-group in Spain, reporting the presence of both X. opisthohysterum and X. duriense, which were almost identical morphologically but genetically different. Recently, phylogenetic analysis for species delimitation in the $X$. americanum-group complex developed by Archidona-Yuste et al. (2016a) as part of a polyphasic study based on morphological and molecular data using the D2-D3 region of $28 S$ gene, showed that the Portuguese and Spanish populations of X. brevisicum (GenBank accession number: AY601610, Portugal; KP268966, Spain) clustered together but were clearly separated from other species that are almost identical morphologically belonging to the $X$. pachydermum subgroup, such as X. duriense (KP268963, Spain), X. opisthohysterum (KP268967, Spain), X. pachydermum (AY601608, Portugal) and X. parapachydermum Gutiérrez-Gutiérrez, Cantalapiedra-Navarrete, Decraemer, Vovlas, Prior, Palomares Rius, \& Castillo, 2012 (KP268970, Spain).

\section{Xiphinema species that are not members of the $X$. americanum-group}

Among the Xiphinema species that do not belong to the X. americanum-group are some major European nepovirus vector nematodes (Decraemer \& Robbins 2007). There is no morphological feature that enables discrimination between non- virus vector and virus vector nematodes inside this group, which is mainly characterized by $i$ ) usually large body (length between 1.4-7.3 mm) and odontostyle (length between 100-160 um); ii) from filiform to hemispherical shape tail; iii) a female reproductive system with usually two equally developed genital branches; and $i v$ ) usually with long bipartite uteri with a tubular part/pars dilatata uteri to tripartite with uterine differentiation, which is mainly characterized by an outer and internal wall differentiated and sclerotized, respectively, and the presence of some well-developed sclerotized apophyses (the 'Z-organ'), slightly developed outer wall with internal wall weakly sclerotized or absent (the 'pseudo-Z-organ'), and the uterine spines or crystalloid bodies in the uterus sometime agglomerated before the beginning the pars dilatata (Brown \& Halbrendt 1997; Coomans et al. 2001; Decraemer \& Chaves 2012). Three of them are recognized as vectors transmitting economically important nepoviruses in Portugal (Brown \& Trudgill 1997; Taylor \& Brown 1997, Decraemer \& Chaves 2012) (Table S1).This group of important phytopathological species has been divided into eight morphospecies groups based on the previously cited characteristics (Brown \& Halbrendt 1997; Decraemer \& Chaves 2012). A total of 25 known Xiphinema species, excluding the americanum group, have been reported to occur in Portugal (Figures 2, 4, 5; Table S1); however, some records of species are considered to be dubious identifications (Table S1).

The majority of Xiphinema spp. species are included in the morphospecies groups 5-8 described by Brown \& Halbrendt (1997). Xiphinema species belonging to morphogroup 5, are characterized by two genital branches with uteri containing Z-differentiations plus spines or crystalloid structures and a dorsally convex-conoid tail with digitate terminus resembling the virus vector $X$. diversicaudatum ( $X$. diversicaudatum-complex), have been 
recorded widely in Portugal since the first report in 1962 (Lima 1962, 1965; Macara 1963; Brown et al.1992; Taylor \& Brown 1997) (Table S1). Xiphinema diversicaudatum is widespread in temperate region of Europe in cool and humid conditions (Brown \& Taylor 1987; Taylor \& Brown 1997; Coomans et al. 2001; Decraemer \& Chaves 2012). This longidorid species has been reported from Continental Portugal and from overseas territories of Madeira and Azores islands) (Brown et al. 1992; Taylor \& Brown 1997; Vieira et al. 2008; Borges 2010; Decraemer \& Chaves 2012) (Table S1) (Figures 2, 4, 5). The X. diversicaudatum populations reported in Portuguese territories show a high inter- and intra-morphometric variability (Lampreia \& Brown 1992), in fact the identification of this species was controversial. The first record of a population of $X$. diversicaudatum was in an apple plantation located in a district of Northern Portugal (Viseu) (Macara 1963; Brown \& Taylor 1987; Brown et al.1992; Taylor \& Brown 1997); however, its identification was later questioned by Pereira (1984) who studied the occurrence of longidorids in strawberry fields in Portugal and reported the presence of a species closely related to $X$. diversicaudatum but with some biometric and morphological differences. Macara (1994) reported a large list of populations belonging to the $X$. diversicaudatum complex, but unfortunately did not include any detailed morphometric and morphological characterizations. Results of the D2-D3 region of $28 S$ gene obtained by Gutiérrez-Gutiérrez et al. (2013) during a morphological and molecular phylogenetic study of subfamily Xiphineminae species belonging to the $X$. diversicaudatum complex suggest that the population of $X$. diversicaudatum (GenBank accession number: AY601624) from northern Portugal, which was not identified on the basis of detailed morphological and morphometric analysis, was a misidentification and should be considered conspecific with $X$. coxi europaeum Sturhan, 1984. Subsequently, the phylogenetic analysis developed by Chizhov et al. (2014), during a polyphasic study based on morphological and molecular data where several new Central European $X$. diversicaudatum populations were incorporated, is in agreement with the idea of Gutiérrez-Gutiérrez et al. (2013b) regarding a misidentification of the Portuguese population (GenBank accession number: AY601624) which should be considered as X. coxi europaeum. During the 1980s two new endemic species belonging to the $X$. diversicaudatum complex were described, Xiphinema lusitanicum Sturhan, 1983 and X. dissimile Roca, Pereira \& Lamberti, 1987 (Sturhan 1983; Roca et al. 1987; Roca \& Bravo 1997). Subsequently, both species were extensively reported in Portuguese vineyards and forest soils (Macara 1994, Bravo \& Lemos 1997, Roca \& Bravo 1997, Coomans et al. 2001) (Figures 2, 4, 5; Table S1). Xiphinema coxi Tarjan 1964, was reported for the first time in Portugal infesting the soil of a conifer tree forest in Estarreja (province of Beira Litoral) (Table S1). Sturhan (1984) established that $X$. coxi was in fact a species subcomplex highly similar morphologically to $X$. diversicaudatum. Unfortunately, these populations of the $X$. coxi subcomplex have never been reviewed, but both $X$. pseudocoxi Sturhan, 1984, and X. coxi europaeum, have later been reported in Portugal (Figure 2; Table S1) as well as from other localities of the Iberian Peninsula (Arias et al. 1986; Abelleira et al. 1996; Gutiérrez-Gutiérrez et al. 2013b). Phylogenetic analysis developed by Gutiérrez-Gutiérrez et al. (2013b) clearly separated several Iberian populations of $X$. coxi europaeum from other Iberian endemic species with highly similar morphology, such as the Portuguese population of X. abrantinum Roca \& Pereira, 1991 (GenBank accession number: AY601625) and the Spanish populations of $X$. belmontense Roca \& Pereira, 1992 (GenBank accession number: KC567170, KC567171, KC567172). During the 1990s, a large number of records were published with descriptions of new Iberian endemic species belonging to the $X$. diversicaudatum complex, including $X$. abrantinum, $X$. belmontense, $X$. cadavalense Bravo \& Roca, 1995 and X. gersoni Roca \& Bravo, 1993 (Figure 2; Table S1). These species belong to the $X$. diversicaudatum complex are considered Iberian endemics (Figure 2; Table S1) but only X. belmontense, $X$. cadavalense and X. gersoni have been reported for Spain (Murillo-Navarro et al. 2005; Peña-Santiago et al. 2006; Gutiérrez-Gutiérrez et al. 2013b). Nematode surveys conducted in the forest nurseries of the Forest Administration in the Northern Portugal by Macara (1994) resulted in the description of a new species, X. amarantum Macara, 1970, but later it was considered to be a synonym of $X$. sahelense Dalmasso, 1969 (Figures 2, 4, 5; Table S1). Macara (1970) characterized this species by having two genital branches with uteri containing a pseudo-Z-organ and a conoid tail with distinctly digitate terminus resembling the $X$. diversicaudatum species complex. Lampreia \& Brown (1992) proposed that the populations described by Macara in 1970 should be a synonymy of $X$. diversicaudatum, since $X$. sahelense did not show Z-differentiations. However, for the description of $X$. amarantum, Macara assigned paratype specimens from several populations, possibly mixing several members of the X. diversicaudatum complex species (Table S1). Xiphinema hispidum Roca \& Bravo, 1994 and X. lupini Roca \& Pereira, 1993 are two Iberian endemic morphospecies in group 5, phylogenetically and morphologically related to the putative virus vector $X$. italiae (morphospecies group 7) (Gutiérrez-Gutiérrez et al. 2011). They were 
described originally from the localities of Palmela (province of Estremadura) and Coruche (province of Ribatejo) (Figure 2; Table S1) and have later been reported extensively from cultivated and natural environments of the Southern Iberian Peninsula (Peña-Santiago et al. 2006; Gutiérrez-Gutiérrez et al. 2011, 2013b). The putative GFLV vector nematode $X$. italiae, one of the most widespread Xiphinema species in the Mediterranean area where it has been associated with many plant species (Brown \& Taylor 1987; Taylor \& Brown 1997; Coomans et al. 2001; Decraemer \& Chaves 2012), was reported for the first time in the locality of Alpiarça (province of Ribatejo) (Lima 1974) and later found infesting several commercial vineyards in sandy soils in Estremadura, Ribatejo and Douro wine regions (Lima 1974; Bravo \& Lemos 1997; Taylor \& Brown 1997; Gutiérrez-Gutiérrez et al. 2015) (Figure 2; Table S1). Currently, this species is not accepted as a vector nematode because GFLV was transmitted by X. italiae under controlled experimental conditions on only one single occasion (Taylor \& Brown 1997), thus not fulfilling the postulate proposed by Trudgill et al. (1983).

Some species belong to morphogroups 5,6 and 8 characterized by a dorsally convex-conoid tail with rounded terminus to almost hemispherical, with an inconspicuous terminal bulge resembling $X$. pyrenaicum ( $X$. pyrenaicum-complex species) were reported in Portugal (Macara 1994; Roca \& Bravo 1993b; Bravo \& Lamberti et al. 1996; Bravo \& Lemos 1997) (Figures 2, 5; Table S1). Xiphinema turcicum Luc \& Dalmasso, 1963 was mentioned for the first time by Bravo (1983) and later reported in association with forest tree species in several locations from the north to the south of the country (Macara 1994). Some populations identified by Bravo (1983) as X. turcicum, were later considered to be two morphologically closely related species previously described in Spain (Lamberti et al. 1992; Gutiérrez-Gutiérrez et al. 2010), X. hispanum Lamberti, Castillo, Gomez-Barcina \& Agostinelli, 1992 and X. sphaerocephalum Lamberti, Castillo, Gomez-Barcina \& Agostinelli, 1992, as well as two new Portuguese endemic species X. lanceolatum Roca \& Bravo, 1993 and X. lapidosum Roca \& Bravo, 1993 (Roca \& Bravo 1993b) (Figure 2; Table S1).

The other species described in Portugal belong to morphospecies group 8 , characterized by two genital branches without Z-differentiations or spines in the uteri and an usually short convex-conoid tail with a digitate ventral or terminal peg resembling the virus vector nematodes X. index (Luc et al. 1964; Macara et al. 1994; Bravo \& Lemos 1997; Taylor \& Brown 1997; Gutiérrez-Gutiérrez et al. 2015) (Figures 2, 5; Table S1). Sequeira \& Dias (1964) reported the transmission of GFLV by Portuguese populations of $X$. index, demonstrating that the virus vector nematodes and their associated viruses were causing severe economic losses in Portugal. At that time, the virus vector nematodes were recognized as a priority subject of study in Portugal. Consequently, a large body of literature reported the occurrence and distribution of the virus vector nematode species during the following thirtyfive years (Figures 2, 5; Table S1). Xiphinema index is widespread in commercial vineyards in the main grapevinegrowing areas of the Mediterranean climate regions (Taylor \& Brown 1997; Coomans et al. 2001; Decraemer \& Robbins 2007; Decraemer \& Chaves 2012) including the Portuguese vineyards of old grapevine-growing areas (Bravo \& Lemos 1997; Gutiérrez-Gutiérrez et al. 2015) (Table S1). Bravo (1983) reported the presence of X. index in $16 \%$ of the Portuguese vineyards of the Oeste Region (now known as Lisbon wine region). Recently, GutiérrezGutiérrez et al. (2015) established that $X$. index is still distributed extensively in vineyards in the same wine area of Portugal with an overall prevalence of $21 \%$ (Gutiérrez-Gutiérrez et al. 2015). The high prevalence of $X$. index makes this species a severe threat to grapevine production in Portugal since in the Portuguese grapevine-growing regions GFLV has also been detected (Santos 2011).

\section{Genus Longidorus}

Among the Longidorus species are some of the major European nepovirus vector nematodes (Decraemer \& Robbins 2007). There are no morphometric and morphological characteristic that enable to discrimination between non-virus vector and virus vector nematodes in this genus, mainly characterized by a large body (length between 3.0-9.0 mm) and odontostyle (length between 80-160 um), a lip region continuous or offset by depression or expanded anteriorly with a border rounded or flattened, amphidial fovea usually more or less pouch-like between shallowly or distinctly bilobed symmetrical or asymmetrical, and a tail usually short, which varies between hemispheroid and elongate-conical (Chen et al. 1997). The first reference on Longidorinae nematodes (Longidorus spp., and Paralongidorus spp.) occurring in Portugal dates from 1962 (Macara 1963). This population from Dois Portos (province of Estremadura) was not identified at species level at that time, but thirty years later at the same 


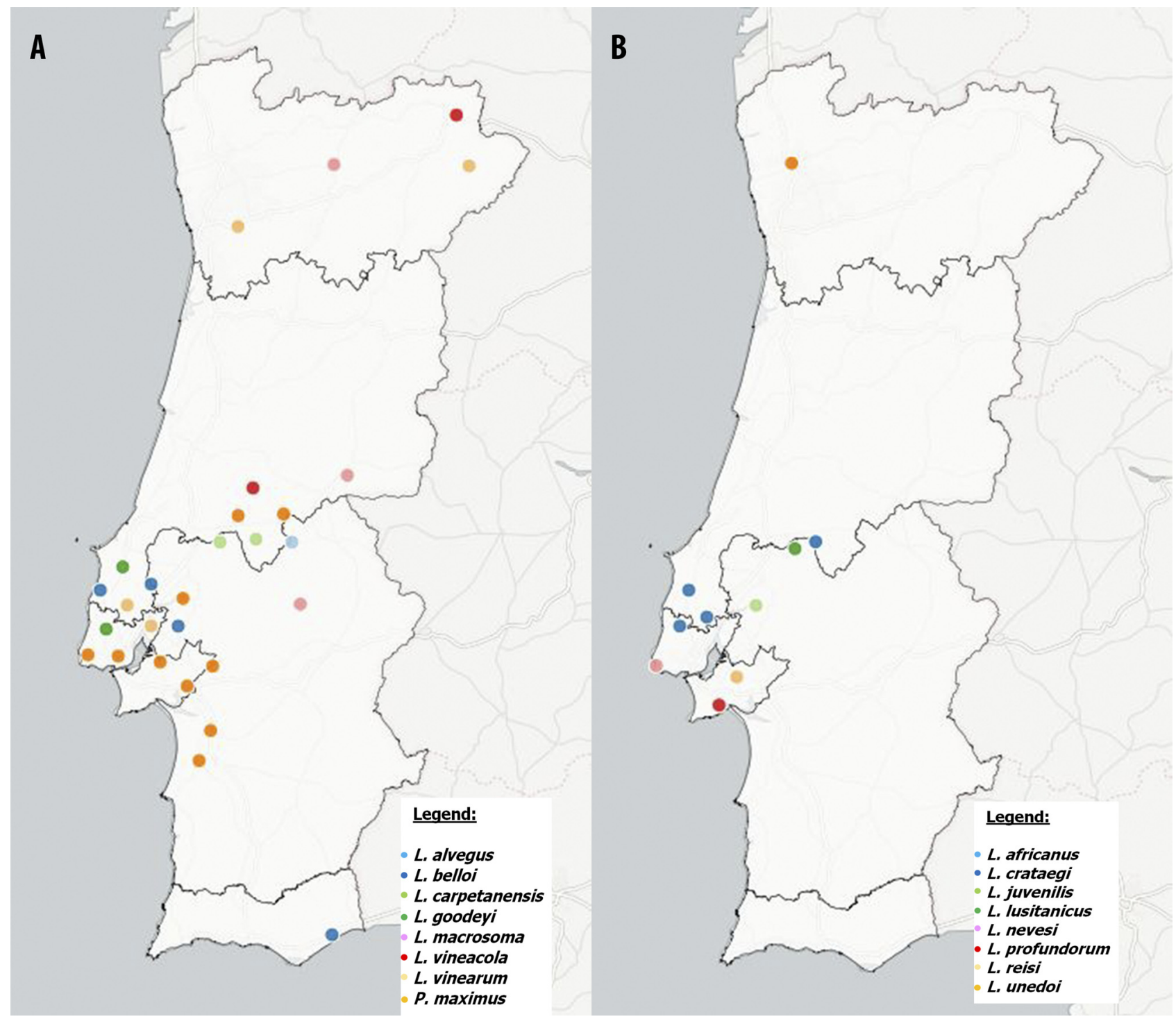

FIGURE 3. Geographic distribution of populations from Longidorus and Paralongidorus species in Continental Portugal: (A) L. alvegus, L. belloi, L. carpetanensis, L. goodeyi, L. macrosoma, L. vineacola, L. vinearum and P. maximus; (B) L. africanus, L. juvenilis, L. crataegi, L. lusitanicus, L. nevesi, L. profundorum, L. reisi and L. unedoi,. This map may be similar but not identical to other published maps of Portugal designed using the mapping software Cartodb. This map is for illustrative purposes only.

locality, infesting the same crop the species L. vinearum Bravo \& Roca, 1995, was identified (Bravo \& Roca 1995). Two new Longidorus species named L. lusitanicus Macara, 1985 and L. nevesi Macara, 1985 were later described (Macara 1985). Both species are considered Iberian endemic species with a large distribution among different forest environments (Brown \& Taylor 1987; Navas et al. 1990, Archidona-Yuste et al. 2016b) (Figure 3; Table S1). The occurrence and distribution in Portugal of two species known as L. macrosoma and L. profundorum Hooper, 1966 has been reported (Taylor \& Brown 1987; Navas et al. 1990; Bravo \& Lemos 1997; Brown \& Taylor 1997) (Figure 3; Table S1). They are phytopathologically important because they are known vectors of Raspberry ringspot virus (RpRSV), and occur in numerous countries in Europe, including the Mediterranean and Iberian countries, although L. macrosoma appears to be more frequent in Central Europe (Navas et al. 1990; Bravo \& Lemos 1997; Taylor \& Brown 1997; Nombela et al. 1998). Later, two morphologically near identical species were described from Portugal: L. alvegus Roca, Pereira \& Lamberti, 1989 and L. reisi Roca \& Bravo, 1993 (Roca et al. 1989b; Roca \& Bravo 1993). These two Longidorus species are considered Iberian endemics (Figure 3; Table S1) but only L. alvegus has been reported for Spain (Brown \& Taylor 1987; Navas et al. 1990; Gutiérrez-Gutiérrez et al. 2011; Archidona-Yuste et al. 2016b). Roca \& Bravo (1996) described a new species named Longidorus crataegi 
Roca \& Bravo, 1996, from several populations found in the rhizosphere of Crataegus oxycantha L. in the southwest region of Portugal (Brown \& Lemos 1997) (Figure 3; Table S1), and subsequently this species has also been reported from a several Spanish localities (Gutiérrez-Gutiérrez et al. 2012b; Archidona-Yuste et al. 2016b). This Iberian endemic species is characterized by a lip region almost flattened frontally and rounded laterally, continuous with the rest of the body, distinctly asymmetrically bilobed amphidial fovea-pouch, and tail conoid-rounded resembling the L. vineacola complex species (Brown et al. 1997; Ye et al. 2003; Archidona-Yuste et al. 2016b). In Portugal, this species complex includes two species, L. vinearum and L. vineacola Sturhan \& Weischer, 1954, which have frequently been found infesting Portuguese vineyards (Bravo \& Roca 1995, 1998; Bravo \& Lemos 1997; Roca \& Bravo 1996; Peña-Santiago et al. 2006) (Figure 3; Table S1). Longidorus vinearum is an Iberian endemic species (Bravo \& Roca 1995, 1998; Archidona-Yuste et al. 2016b; Gutiérrez-Gutiérrez, unpublished data), whilst $L$. vineacola has been extensively reported from the Mediterranean Basin and Central Europe (i.e. Belgium, Bulgaria, England, France, Greece, Germany, Israel, Jordan, Moldavia, Netherlands, Portugal, Scotland and Spain), although also have been reported in some regions of Central Asia (Russian) (Boag \& Brown 1987; Navas et al. 1990; Taylor \& Brown 1997; Brown et al. 1997; Ye et al. 2003; Gutiérrez-Gutiérrez et al. 2012b; Archidona-Yuste et al. 2016b). Several new records of Longidorus species in the Iberian Peninsula were reported (Bravo \& Lemos 1997) (Figure 3; Table S1) but no morphological and morphometric analyses were made, except in the descriptions of some Longidorus populations (Bravo \& Roca 1995, 1998; Roca \& Bravo 1996).

\section{Genus Paralongidorus}

Lima in 1968 recorded for the first time the genus Paralongidorus as occurring in soils of eucalyptus and cypresspine forests and other natural woodlands (Macara 1994) (Table S1). Subsequently, this species was collected from soil around roots of seedlings in forest nurseries at several localities (Macara 1982, 1994) and identified for the first time in Portugal as Siddiqia maxima (Bütschli, 1874) Khan, Chawla \& Saha, 1978 (Macara, 1982); it was subsequently transferred to the genus Paralongidorus Sidiqqi, Hopper \& Khan, 1963 (=P. maximus (Bütschli, 1874) Siddiqi, 1964). Paralongidorus maximus is the most common and widespread species of the genus and is a vector of RpRSV (Brown \& Taylor 1987; Bravo \& Lemos 1997; Taylor \& Brown 1997) (Figure 3; Table S1). This species has been detected in some Mediterranean countries and the Iberian Peninsula (Brown \& Taylor 1987; Lamberti et al. 1983, Taylor \& Brown 1997, Lišková \& Brown 2003); however, it appears that its geographical distribution is restricted to central European countries where it is commonly found associated with forests and vineyards (Taylor \& Brown 1997). Of the seven valid Paralongidorus species described in Europe, five of them have been reported to be present in Spain (Palomares-Rius et al. 2013) and one of them in Portugal (Bravo \& Lemos 1997; Taylor \& Brown 1997).

\section{Conclusions}

This review has been undertaken to compile all information available from papers, books and databases, as well as unpublished data of the authors, to include new records and those data that were overlooked, update maps of distribution of species, and clarify the taxonomic position of some species with dubious identifications. Three Xiphinema spp. (X. pombalense Bravo \& Lamberti, 1996, X. cadavalense Bravo \& Roca, 1995, X. silvesi Roca, 1998) and one Longidorus spp. (L. crataegi Roca \& Bravo, 1996) are added to update the list of nematodes species from the family Longidoridae in Portugal proposed by Bravo \& Lemos in 1997 (Table S1), as well as several new records of other previously reported species such as $L$. vineacola, $L$. vinearum, $X$. coxi europaeum, $X$. italiae, $X$. lusitanicum, X. pachtaicum, X. pseudocoxi, X. sahelense and X. santos (Bravo \& Roca 1995, 1998; Roca \& Bravo 1996, 1997, 1998; Bravo et al. 2001; Gutiérrez-Gutiérrez et al. 2015; Bravo, unpublished data;. GutiérrezGutiérrez, unpublished data). According to the data presented, a total of 56 species have been recorded as present in Portugal; however, in this review we propose that some populations identified as X. coxi, X. diversicaudatum and $X$. sahelense should be considered as populations with a doubtful identity, requiring further investigation. Longidorid species richness appears to be higher in the Iberian Peninsula (Portugal and Spain) than in the rest of Europe, which could be due to this region possibly being the centre of origin for a large number of longidorid 
species because of the high number of endemic species. A total of twenty (four Longidorus and sixteen Xiphinema) species are tentatively considered as endemic to Portugal since their current distribution is restricted to Portugal; in addition, thirteen other (five Longidorus and eight Xiphinema) species are regarded as endemic to the Iberian Peninsula. This high biodiversity present in the Portuguese territory confirms the importance of this group of phytopathogenic species in this region.
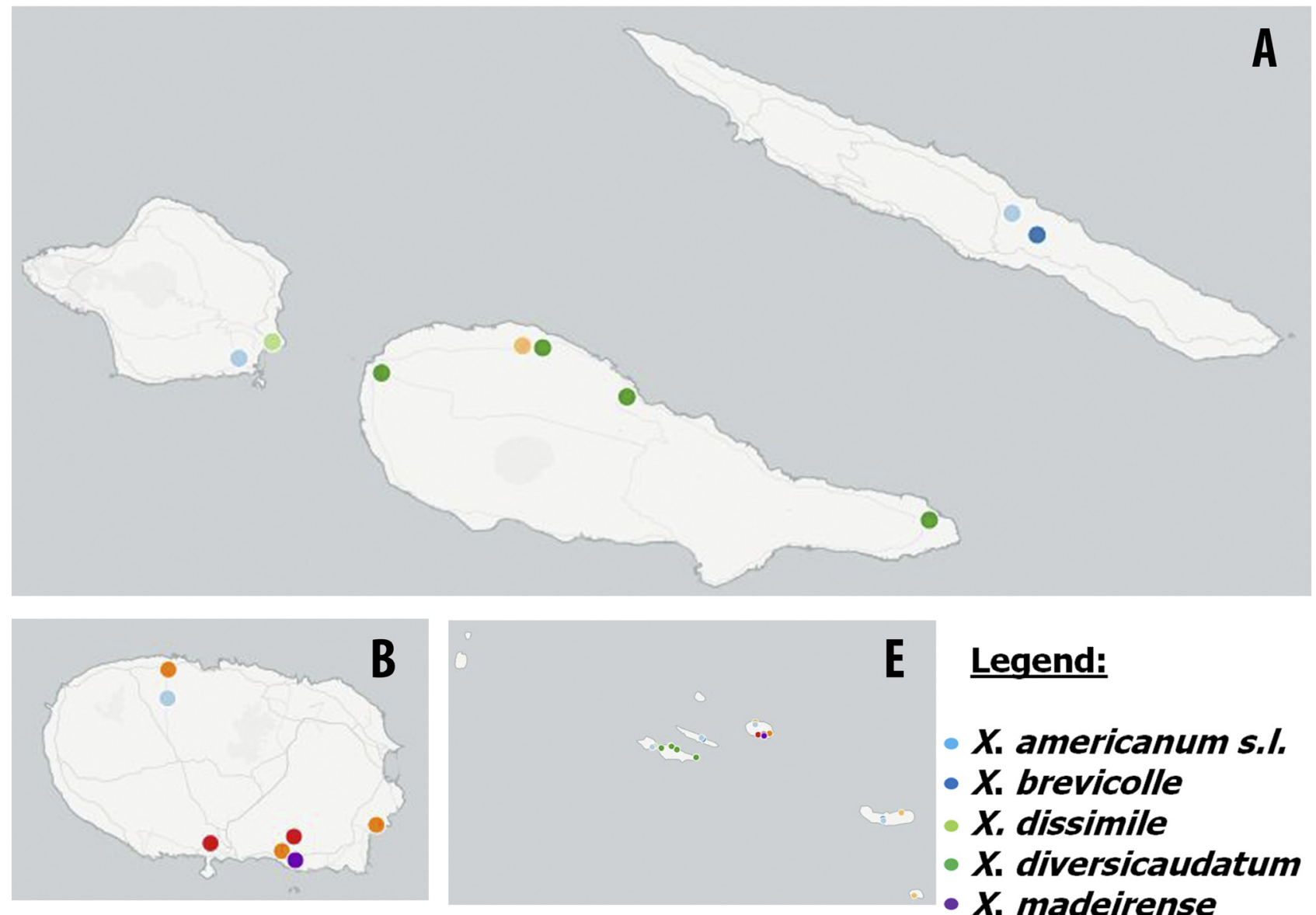

\section{Legend:}

$X$. americanum s.l.

- $X$. brevicolle

$X$, dissimile

- $X$. diversicaudatum

- $X$. madeirense

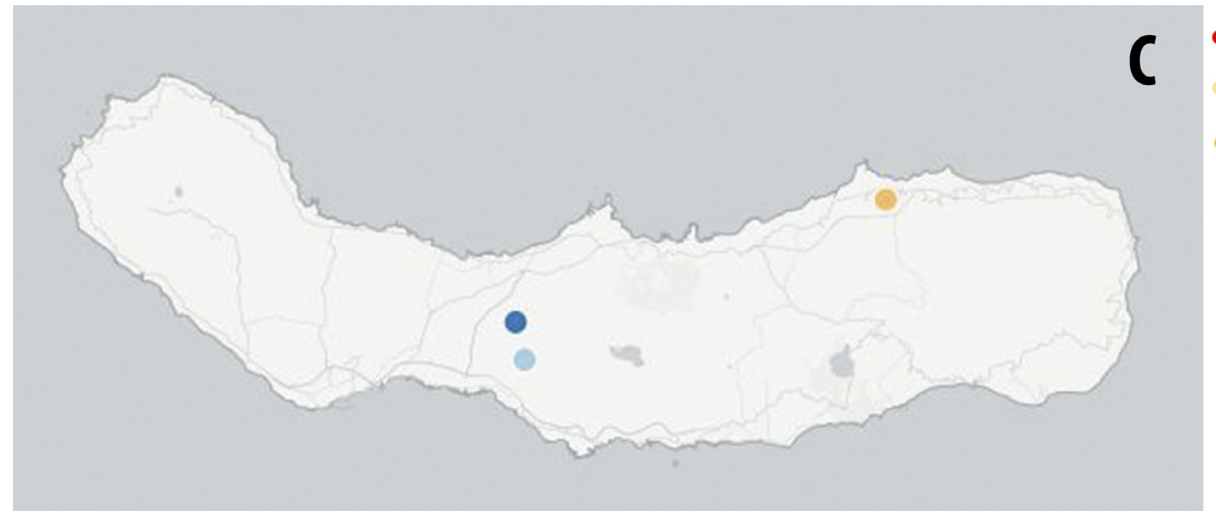

- X. pachtaicum

$X$. sahelense

$X$. santos

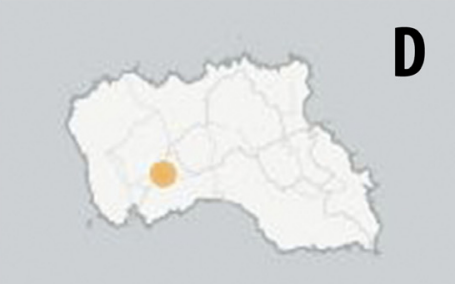

FIGURE 4. Geographic distribution of populations from longidorid species present in Azores Islands: (A) Sao Jorge, Pico and Faial islands; (B) Terceira; (C) Sao Miguel island; (D) Santa Maria island; (E) Azores islands. This map may be similar but not identical to other published maps of Azores Islands and designed using the mapping software Cartodb. This map is for illustrative purposes only. 


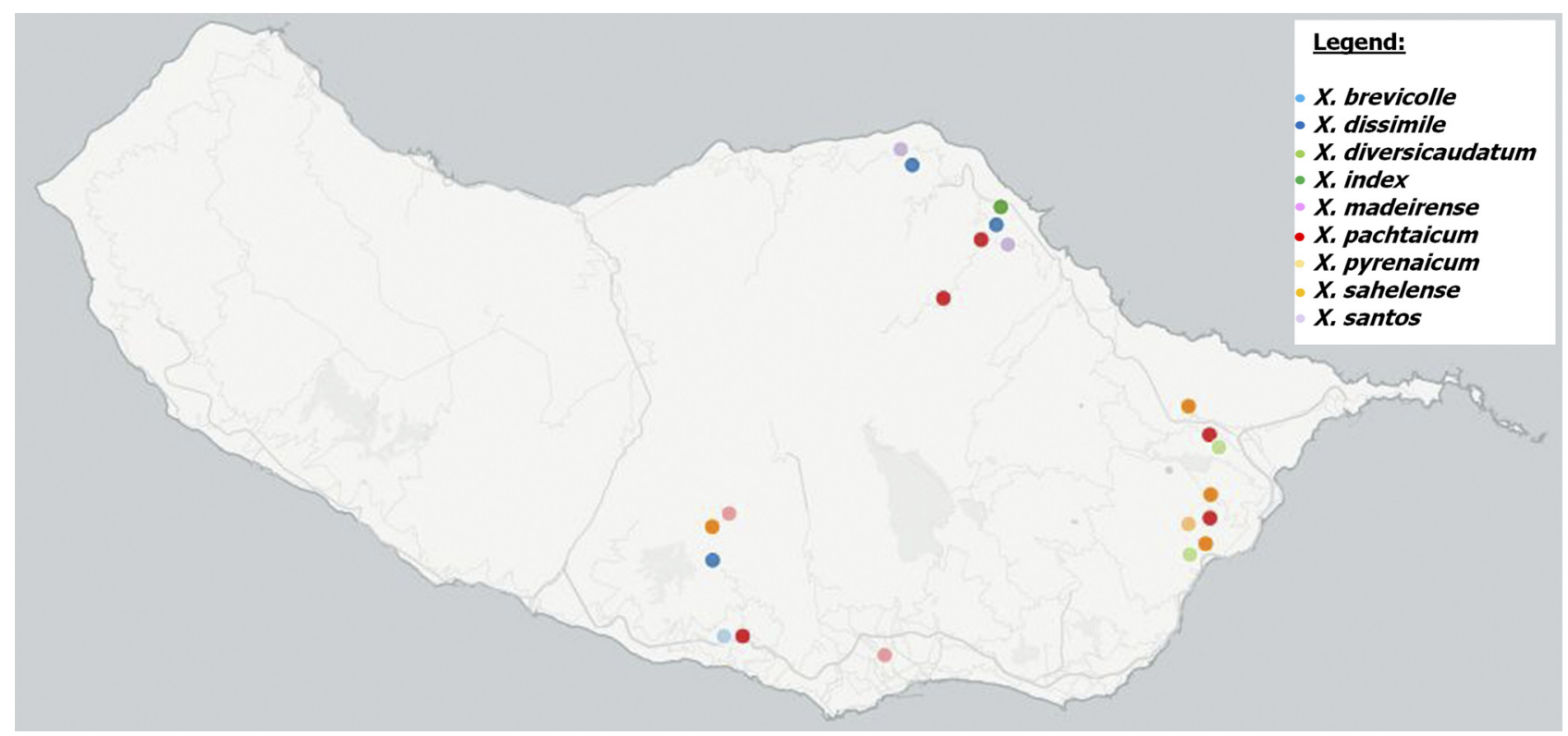

FIGURE 5. Geographic distribution of populations from longidorid species present in Madeira Island. This map may be similar but not identical to other published maps of Madeira Island designed using the mapping software Cartodb. This map is for illustrative purposes only.

\section{Acknowledgements}

This research was supported by FCT - Foundation for Science and Technology postdoctoral fellowship SFRH/ BPD/95315/2013 and FEDER Funds through the Operational Programme for Competitiveness Factors COMPETE and National Funds through FCT under the Strategic Projects PEst-C/AGR/UI0115/2011 and PEst-OE/ AGR/UI0115/2014. The authors thank I. Ferreira from Instituto de Ciências Agrárias e Ambientais Mediterrânicas (ICAAM)-Universidade de Évora (Evora, Portugal) for the excellent technical assistance and Roland N. Perry from School of Life and Medical Sciences at the University of Hertfordshire (Hertfordshire, UK) for their critically reading the manuscript prior to submission.

\section{References}

Abelleira, A., Mansilla, J.P. \& Arias, M. (1996) Xiphinema coxi europaeum Sturhan asociados con daños en viveros de coníferas en Galicia. Boletín de Sanidad Vegetal-Plagas, 22, 551-556.

Andret-Link, P., Laporte, C., Valat, L., Ritzenthaler, C., Demangeat, G., Vigne, E., Laval, V., Pfeiffer, P., Stussi-Garaud, C. \& Fuchs, M. (2004) Grapevine fanleaf virus: still a major threat to the grapevine industry. Journal of Plant Pathology, 86, 183-95.

Archidona-Yuste, A., Navas-Cortés, J.A., Cantalapiedra-Navarrete, C., Palomares-Rius, J.E. \& Castillo, P. (2016a) Cryptic diversity and species delimitation in the Xiphinema americanum-group complex (Nematoda: Longidoridae) as inferred from morphometrics and molecular markers. Zoological Journal of the Linnean Society, 176, 231-265. http://dx.doi.org/10.1111/zoj.12316

Archidona-Yuste, A., Navas-Cortés, J.A., Cantalapiedra-Navarrete, C., Palomares-Rius, J.E. \& Castillo, P. (2016b) Unravelling the biodiversity and molecular phylogeny of needle nematodes of the genus Longidorus (Nematoda: Longidoridae) in olive and a description of six new species. PLOS ONE, 11, e0147689.

http://dx.doi.org/10.1163/156854108783360212

Arias, M., Andres, M.F. \& Navas, A. (1986) Longidorus carpetanensis sp. n. and L. unedoi sp. n. (Nematoda: Longidoridae) from Spain. Revue de Nématologie, 9, 101-106.

Barsi, L. \& De Luca, F. (2008) Morphological and molecular characterisation of two putative Xiphinema americanum group species, X. parasimile and X. simile (Nematoda: Dorylaimida) from Serbia. Nematology, 10, 15-25. http://dx.doi.org/10.1163/156854108783360212

Boag, B. \& Brown, D.J.F. (1987) The occurrence of Longidorus vineacola in Scotland with notes on its distribution in Europe. 
Nematologia Mediterranea, 15, 51-57.

Borges, P.A.V. (2010) List of the terrestrial nematodes (Nematoda) from Azores.. In: Borges, P.A.V., Costa, A., Cunha, R., Gabriel, R., Gonçalves, V., Martins, A.F., Melo, I., Parente, M., Raposeiro, P., Rodrigues, P., Santos, R.S., Silva, L., Vieira, P. \& Vieira, V. (Eds.), A list of the terrestrial and marine biota from the Azores. Princípia, Cascais, pp. 157-164.

Bravo, M.A, Roca, F. \& Mota, M.M. (2001) Observations on Xiphinema coxi europaeum Sturhan from Portugal and description of the male of $X$. lusitanicum Sturhan (Nematoda: Longidoridae) with multivariate analysis of juveniles. International Journal of Nematology, 11, 15-26.

Bravo, M.A. \& Lemos, R.M. (1997) Longidorus, Paralongidorus and Xiphinema in Portugal. In: Santos, M.S. de A., Abrantes, I. O., Brown, D.J.F. \& Lemos, R.M. (Eds.), An introduction to virus vector nematodes and their associated viruses. Instituto do Ambiente e Vida, Universidade de Coimbra, Coimbra, pp. 421-441.

Bravo, M.A. \& Roca, F. (1995) Observations on Longidorus africanus Merny from Portugal with description of L. vinearum sp. n. (Nematoda: Longidoridae). Fundamental and Applied Nematology, 18, 97-84.

Bravo, M.A. \& Roca, F. (1998) Two Longidorus species (Nematoda: Longidoridae) occurring in the rhizosphere of olive trees in Northeastern Portugal. Agronomia Lusitanica, 46, 101-121.

Bravo, M.A. (1983) Nemátodos vectores de viroses da videira. Encontro de Técnicos de Viticultura. Ministerio de Agricultura Forestal e Alimentação, EAN, Oeiras, pp. 1-6.

Bravo, M.A. (1989) Especies de nemátodes da familia Longidoridae em Portugal, Madeira e Açores. Summa Phytopathologica, $15,46$.

Brown, D. F., Faria, A., Lamberti, F., Halbrendt, M., Agostinelli, A. \& Jones, A.T. (1992) A description of X. madeirense sp.n. and the occurrence and virus vector potential of $X$. diversicaudatum (Nematoda: Dorylaimida) from Santana, Madeira. Nematologia Mediterranea, 20, 251-259.

Brown, D.J.F. \& Halbrendt, J.M. (1997) Identification of Xiphinema species (Nematoda: Dorylaimoidea). In: Santos, M.S.N.A., Abrantes, I.M.O., Brown, D.J.F. \& Lemos, R.M. (Eds.), An introduction to virus vector nematodes and their associated viruses. Instituto do Ambiente e Vida, Coimbra, pp. 177-223.

Brown, D.J.F. \& Taylor, C.E. (1987) Comments on the occurrence and geographical distribution of longidorid nematodes in Europe and the Mediterranean region. Nematologia Mediterranea, 15, 333-373.

Brown, D.J.F., Neilson, R., Connolly, T. \& Boag, B. (1997) An assessment of morphometric variability between populations of Longidorus vineacola Sturhan \& Weischer, 1964 (Nematoda: Longidoridae) and morphologically related species. Systematic Parasitology, 37, 93-103. http://dx.doi.org/10.1023/A:1005713123568

Chen, Q.W., Hooper, D.J., Loof, P.A.A. \& Xu, J. (1997) A revised polytomous key for the identification of species of the genus Longidorus Micoletzky, 1922 (Nematoda: Dorylaimoidea). Fundamental and Applied Nematology, 20, 15-28.

Chizhov, V.N., Pridannikov, M.V., Peneva, V. \& Subbotin, S.A. (2014) Morphological and molecular characterisation of the Saratov population of the European dagger nematode, Xiphinema diversicaudatum (Nematoda: Dorylaimida), with notes on phylogeography of the species. Nematology, 16, 847-862. http://dx.doi.org/10.1163/15685411-00002813

Coomans, A., Huys, R., Heyns, J. \& Luc, M. (2001) Character analysis, phylogeny, and biogeography of the genus Xiphinema Cobb, 1913 (Nematoda, Longidoridae). Vol. 287. Annales du Musée Royal de l'Afrique Centrale (Zoologie), Tervuren, Belgique, $239 \mathrm{pp}$.

Decraemer, W. \& Chaves, E. (2012) Chapter 15. Longidoridae and Trichodoridae. In Manzanilla-Lopez, R. \& Marban Mendoza, N. (Eds.), Practical Plant Nematology. Fundacion Colegio de Posgraduados and Mundi Prensa, Mexico, pp. 579-617.

Decraemer, W. \& Geraert, E. (2013) Ectoparasitic nematodes. In: Perry R. N. \& Moens, M. (Eds.), Plant Nematology. $2^{\text {nd }}$ Edition. CABI, Wallingford, pp. 199-202. http://dx.doi.org/10.1079/9781780641515.0179

Decraemer, W. \& Robbins, R.T. (2007) The Who, What and Where of Longidoridae and Trichodoridae. Journal of Nematology, 39, 295-297.

EPPO web (2016) European and Mediterranean Plant Protection Organization. Available from: http://www.eppo.int/ (accessed 19 October 2016)

Escuer, M. \& Arias, M. (1997) Paralongidorus iberis sp. n. and P. monegrensis sp. n. from Spain with a polytomous key to the species of the genus Paralongidorus Siddiqi, Hooper \& Khan, 1963 (Nematoda: Longidoridae). Fundamental and Applied Nematology, 20, 135-148.

Esmaeili, M., Heydari, R., Archidona-Yuste, A., Castillo, P. \& Palomares-Rius, J.E. (2016) A new needle nematode, Longidorus persicus n. sp. (Nematoda: Longidoridae), from Kermanshah province, western Iran. European Journal of Plant Pathology, 1-15. [published online] http://dx.doi.org/10.1007/s10658-016-0976-9

Getaneh, G., Bert, W. \& Decraemer, W. (2015) First report, morphological and molecular characterization of Xiphinema elongatum and X. pachtaicum (Nematoda, Longidoridae) from Ethiopia. ZooKeys, 489, 1-13. http://dx.doi.org/10.3897/zookeys.489.8629

Gutiérrez-Gutiérrez, C., Bravo, M.A., Santos, M.T., Vieira, P. \& Mota, M. (2015) Integrative approach and molecular barcoding of dagger and needle nematodes infesting grapevine soils in Portugal. Scientific abstracts from the 6th 
International Barcode of Life Conference. Genome, 58, 163-303.

http://dx.doi.org/10.1139/gen-2015-0087

Gutiérrez-Gutiérrez, C., Cantalapiedra-Navarrete, C., Decraemer, W., Vovlas, N., Prior, T., Palomares-Rius, J.E. \& Castillo, P. (2012) Phylogeny, diversity, and species delimitation in some species of the Xiphinema americanum-group complex (Nematoda: Longidoridae), as inferred from nuclear and mitochondrial DNA sequences and morphology. European Journal of Plant Pathology, 134, 561-597.

http://dx.doi.org/10.1007/s10658-012-0039-9

Gutiérrez-Gutiérrez, C., Cantalapiedra-Navarrete, C., Montes-Borrego, M., Palomares-Rius, J.E. \& Castillo, P. (2013a) Molecular phylogeny of the nematode genus Longidorus (Nematoda: Longidoridae) with description of three new species. Journal of the Linnean Society, 167, 473-500. http://dx.doi.org/10.1111/zoj.12019

Gutiérrez-Gutiérrez, C., Cantalapiedra-Navarrete, C., Remesal, E., Palomares-Rius, J.E., Navas-Cortés, J.A. \& Castillo, P. (2013b) New insight into the identification and molecular phylogeny of dagger nematodes of the genus Xiphinema (Nematoda: Longidoridae) with description of two new species. Journal of the Linnean Society, 169, 548-579. http://dx.doi.org/10.1111/zoj.12071

Gutiérrez-Gutiérrez, C., Palomares-Rius, J.E., Cantalapiedra-Navarrete, C., Landa, B.B. \& Castillo, P. (2011) Prevalence, polyphasic identification, and molecular phylogeny of dagger and needle nematodes infesting vineyards in southern Spain. European Journal of Plant Pathology, 129, 427-453. http://dx.doi.org/10.1007/s10658-010-9705-y

Handoo, Z.A., Carta, L.K., Skantar A.M., Subbotin, S.A. \& Fraedrich, S.W. (2016) Molecular and morphological characterization of Xiphinema chambersi population from live oak in Jekyll Island, Georgia, with comments on morphometric variations. Journal of Nematology, 48, 20-27.

He, Y., Subbotin, S., Rubtsova, T.V., Lamberti, F., Brown, D.J.F. \& Moens, M. (2005) A molecular phylogenetic approach to Longidoridae (Nematoda: Dorylaimida). Nematology, 7, 111-124. http://dx.doi.org/10.1163/1568541054192108

Hewitt, W.B., Raski, D.J. \& Goheen, A.C. (1958) Nematode vector of soil-borne fanleaf virus of grapevines. Phytopathology, $48,586-595$.

Jones, J.T., Haegeman, A., Danchin, E.G.J., Gaur, H.S., Helder, J., Jones, M.G.K. Kikuchi, T., Manzanilla-Lopez, R., Palomares-Rius, J.E., Wesemael, W.M.L. \& Perry, R.N. (2013) Top 10 plant-parasitic nematodes in molecular plant pathology. Molecular Plant Pathology, 14, 946-961. http://dx.doi.org/10.1111/mpp.12057

Lamberti, F. \& Bleve-Zacheo, T. (1979) Studies on Xiphinema americanum sensu lato with descriptions of fifteen new species (Nematoda, Longidoridae). Nematologia Mediterranea, 7, 51-106.

Lamberti, F. \& Ciancio, A. (1993) Diversity of Xiphinema americanum-group species and hierarchical cluster analysis of morphometrics. Journal of Nematology, 25, 332-343.

Lamberti, F., Agostinelli, A. \& Radicci, V. (1996) Longidorid nematodes from northern Egypt. Nematologia Mediterranea, 24, 307-339.

Lamberti, F., Bravo, M.A., Agostinelli, A. \& Lemos, R.M. (1994) The Xiphinema americanum-group in Portugal with descriptions of four new species (Nematoda, Dorylaimida). Nematologia Mediterranea, 22, 189-218.

Lamberti, F., Castillo, P., Gomez-Barcina, A. \& Agostinelli, A. (1992) Description of six new species of Xiphinema (Nematoda, Dorylaimida) from the Mediterranean region. Nematologia Mediterranea, 20, 125-139.

Lamberti, F., Choleva, B. \& Agostinelli, A. (1983) Longidoridae from Bulgaria (Nematoda, Dorylaimida) with descriptions of three new species of Longidorus and two new species of Xiphinema. Nematologia Mediterranea, 11, 49-72.

Lamberti, F., Hockland, S., Agostinelli, A., Moens, M. \& Brown, D.J.F. (2004) The Xiphinema americanum group. 3. Keys to species identification. Nematologia Mediterranea, 32, 53-56.

Lamberti, F., Lemos, R.M., Agostinelli, A. \& D'addabo, T. (1993) The Xiphinema americanum group in the vineyards of the Dão and Douro regions (Portugal) with description of two new species (Nematoda, Dorylaimida). Nematologia Mediterranea, 21, 215-225.

Lamberti, F., Molinari, S., Moens, M. \& Brown, D.J.F. (2000) The Xiphinema americanum group. I. Putative species, their geographical occurrence and distribution, and regional polytomous identification keys for the group. Russian Journal of Nematology, 8, 65-84.

Lampreia, M.A.B. \& Brown, D.L.F. (1992) The Xiphinema diversicaudatum-complex in Portugal. Nemalologica, 38, $418-419$.

Lazarova, S., Peneva, V. \& Kumari, S. (2016) Morphological and molecular characterisation, and phylogenetic position of $X$. browni sp. n., X. penevi sp. n. and two known species of Xiphinema americanum-group (Nematoda, Longidoridae). ZooKeys, 574, 1-42. http://dx.doi.org/10.3897/zookeys.574.8037

Lazarova, S.S., Malloch, G., Oliveira, C.M.G., Hübschen, J. \& Neilson, R. (2006) Ribosomal and Mitochondrial DNA Analyses of Xiphinema americanum-group populations. Journal of Nematology, 38, 404-410.

Lemos, R.M., Almeida, M.T.M. de, Santos, M.S.N. de A., Abrantes, I.M.D. de O., Martins, A.I.T. \& Reval, J.C.B. de M. (1990) Studies of Portuguese populations of Longidorids and Trichodorids. Nematologica, 36, 366.

Lima, M.B. (1962) Introdução ao estudo dos nemátodos de Portugal Continental. Rel. Final Curso Eng. Agrónomo, Instituto Superior de Agronomia, Universidade Técnica, Lisboa, 141 pp.

Lima, M.B. (1965) Studies on the species of the genus Xiphinema. Ph. D. Thesis, University of London, London, 165 pp. 
Lima, M.B. (1968) A numerical approach to the Xiphinema americanum complex. In: Comptes Rendus VIII Symposium International de Nématologie. Antibes, France, 1965. E.J. Brill, Leiden, pp. 30.

Lima, M.B. (1974) Xiphinema italiae Meyl, 1953 (Nematoda: Dorylaimida) found around roots of grapevine in Portugal. Agronomia Lusitana, 35, 273-276.

Lišková, M. \& Brown, D.J.F. (2003) Longidoridae (Nematoda: Dorylaimida) in the Slovak Republic. Helminthologia, 40, 165172.

Luc, M., Coomans, A., Loof, P.A.A. \& Baujard, P. (1998) The Xiphinema americanum-group (Nematoda: Longidoridae). 2. Observations on Xiphinema brevicollum Lordello \& da Costa, 1961 and comments on the group. Fundamental and Applied Nematology, 21, 475-490.

Luc, M., Lima, M.B., Weischer, B. \& Flegg, J.J.M. (1964) Xiphinema vuittenezi n. sp. (Nematoda: Dorylaimidae). Nematologica, 10, 151-163. http://dx.doi.org/10.1163/187529264X00781

Macara, A.M. (1963) Aspectos sobre a importância do nemátodos de interesse agricola em Portugal e no Ultramar português. Agros, 46, 367-384.

Macara, A.M. (1970) Xiphínema amarantum sp. nov. (Nematoda: Dorylaimidae). Revista Ibérica de Parasitologia, 30, 649658.

Macara, A.M. (1982) First record of Siddiqia maximus (Nematoda: Longidoridae) in Portugal. Garcia de Orta, Serie de Estudos Agronomicos, 9 (1-2), 309-320.

Macara, A.M. (1985) Two new species of Longidorus (Nematoda, Longidoridae) associated with forest plants in Portugal. Nematologica, 31, 410-423. http://dx.doi.org/10.1163/187529285X00508

Macara, A.M. (1994) Nematodes associated with forest plants in Portugal (no período de 1987-1992). Revista de Ciências Agrárias, 17, 77-126.

Molinari, S., De Luca, F., Lamberti, F. \& De Giorgi, C. (1997) Molecular methods for the identification of longidorid nematodes. Nematologia Mediterrenea, 25, 55-61.

Molinari, S., Lamberti, F., Duncan, L.W., Halbrendt, J., Kotcon, J., Abawi, G.S., Robbins, R.T., Nyczepir, A.P., Mchenry, M., Magunacelaya, J.C., Crozzoli, R., Lemos, R.M., Nagy, P., Moens, M. \& Brown, D.J.F. (2004) SOD polymorphism in Xiphinema americanum group (Nematoda: Longidoridae). Nematology, 6, 867-876. http://dx.doi.org/10.1163/1568541044038579

Navas, A., Baldwin, J.G., Barrios, L. \& Nombela, G. (1993) Phylogeny and biogeography of Longidorus (Nematoda: Longidoridae) in Euromediterranea. Nematologia Mediterranea, 21,71-88.

Navas, A., Fe Andres, M. \& Arias, M. (1990) Biogeography of Longidoridae in the Euromediterranean area. Nematologia Mediterranea, 18, 103-112.

Nombela, G., Navas, A. \& Bello, A. (1998) Effects of crop rotations of cereals with vetch and fallow on soil nematofauna in central Spain. Nematologica, 44, 63-80. http://dx.doi.org/10.1163/005225998X00073

Oliveira, C.M.G., Fenton, B., Malloch, G., Brown, D.J.F. \& Neilson, R. (2005) Development of species-specific primers for the ectoparasitic nematodes species $X$. brevicolle, X. diffusum, X. elongatum, X. ifacolum and X. longicaudatum (Nematoda: Longidoridae) based on ribosomal DNA sequences. Annals of Applied Biology, 146, 281-288. http://dx.doi.org/10.1111/j.1744-7348.2005.040031.x

Oliveira, C.M.G., Ferraz, L.C.C.B. \& Neilson, R. (2006) Xiphinema krugi, species complex or complex of cryptic species? Journal of Nematology, 38, 418-428.

Palomares-Rius, J.E., Cantalapiedra-Navarrete, C., Gutiérrez- Gutiérrez, C., Liebanas, G. \& Castillo, P. (2013) Morphological and molecular characterisation of Paralongidorus plesioepimikis n. sp. (Nematoda: Longidoridae) from southern Spain. Nematology, 15, 363-378.

http://dx.doi.org/10.1163/15685411-00002680

Peña-Santiago, R., Abolafia, J., Guerrero, P., Liébanas, G. \& Peralta, M. (2006) Soil and freshwater nematodes of the Iberian fauna: a synthesis. Graellsia, 62, 179-198. http://dx.doi.org/10.3989/graellsia.2006.v62.i2.65

Pereira, M.J. \& Roca, F. (1992) The occurrence of Xiphinema pseudocoxi Sturhan (Nematoda, Longidoridae) in Portugal. Nematologica, 38, 428.

Pereira, M.J. (1980) Situação nematológica dos campos de pés-mães de videira na Direcção Regional do Alentejo. $1^{o}$ Congresso Português de Fitiatria e Fitofarmacologia, Lisboa, Portugal, II, 137-145.

Pereira, M.J. (1984) Prospecção de nemátodos (Xiphinema e Longidorus) em campos de multiplicação de morangueiros. ExDirecção Geral de Protecção da Produção Agrícola, Documento PPA (SVD), Lisboa, No 12/84, 6 pp.

Roca, F. \& Bravo, M.A. (1998) Description of Xiphinema silvesi n. sp. in Portugal (Nematoda: Longidoridae). Fundamental and Applied Nematology, 21, 389-392.

Roca, F. \& Bravo, M.A. (1993a) Longidorus reisi sp. n. (Nematoda: Longidoridae) from Portugal. Fundamental and Applied Nematology, 16, 401-405.

Roca, F. \& Bravo, M.A. (1993b) The occurrence of Xiphinema sphaerocephalum Lamberti et al. and X. hispanum Lamberti et al. (Nematoda: Longidoridae) in Portugal with descriptions of $X$. lanceolatum sp. n. and X. lapidosum sp. n. Fundamental and Applied Nematology, 16, 455-465.

Roca, F. \& Bravo, M.A. (1993c) Xiphinema gersoni sp. n. (Nematoda: Longidoridae) from Portugal. Fundamental and Applied 
Nematology, 16, 543-547.

Roca, F. \& Bravo, M.A. (1994) Xiphinema hispidum sp. n. (Nematoda: Longidoridae) from Portugal. Fundamental and Applied Nematology, 17, 79-84

Roca, F. \& Bravo, M.A. (1996) Description of Longidorus crataegi sp. n. from Portugal and observations on L. vineacola Sturhan \& Weischer (Nematoda: Longidoridae). Fundamental and Applied Nematology, 19, 529-535

Roca, F. \& Bravo, M.A. (1997) Multivariate analysis of Xiphinema diversicaudatum and some related species (Nematoda: Longidoridae). Fundamental and Applied Nematology, 20, 357-369.

Roca, F. \& Pereira, M.J. (1991) Xiphinema abrantinum sp. n. (Nematoda: Longidoridae) from Portugal. Revue de Nematologie, 14, 485-490.

Roca, F. \& Pereira, M.J. (1992) Xiphinema belmontense sp. n. (Nematoda: Longidoridae) from Portugal. Fundamental and Applied Nematology, 15, 251-255.

Roca, F. \& Pereira, M.J. (1993) Xiphinema lupini sp. n. (Nematoda: Longidoridae) from Portugal. Fundamental and Applied Nematology, 16, 515-519.

Roca, F., Lamberti, F., Santos, M.S.N. de A. \& Abrantes, I.M. de O. (1989a) Xiphinema diversum and X. exile (Nematoda, Dorylaimida), two new species from Portugal. Nematologia Mediterranea, 16, 213-219.

Roca, F., Pereira, M.J. \& Lamberti, F. (1987) Two new Xiphinema species (Nematoda: Longidoridae) from Portugal. Nematologia Mediterranea, 15, 323-332.

Roca, F., Pereira, M.J. \& Lamberti, F. (1989b) Longidorus alvegus sp. n. (Nematoda, Dorylaimida) from Portugal. Nematologia Mediterranea, 17, 1-4.

Santos, M.T. (2011) Os vírus do urticado e do enrolamento foliar da videira. In: Agrorrural: contributos cientificos. INCM, Lisboa, pp. 650-658.

Sequeira, O.A. \& Dias, H.F. (1964) Transmissão do vírus do urticado da videira pelo nemátodo $X$. index Thorne et Allen. Agronomia Lusitana, 24, 307-316.

Siddiqi, M.R., Hooper, D.J. \& Khan, E. (1963) A new nematode genus Paralongidorus (Nematoda : Dory 1aimoidea) with description of two new species and observations on Paralongidorus citri (Siddiqi, 1959) n. comb. Nematologica, 9, 7-14. http://dx.doi.org/10.1163/187529263X00025

Sturhan, D. (1973) Ergebnisse der forschungsreise auf die Azoren, 1969. Internationales Forchungsproject Makaronesischer Raum. II Zur Nematodenfauna der Azoren. Boletim do Museu Municipal do Funchal, 27, 18-25.

Sturhan, D. (1983) Description of two new Xiphinema species from Portugal, with notes on X. pachtaicum and X. opisthohysterum (Nematoda, Longidoridae). Nematologica, 29, 270-283. http://dx.doi.org/10.1163/187529283X00032

Sturhan, D. (1984) Untersuchungen über den Xiphinema coxi-komplex (Nematoda: Longidoridae). Nematologica, 30, 305323. http://dx.doi.org/10.1163/187529284X00211

Subbotin, S., Rogozhin, E. \& Chizhov, V. (2014) Molecular characterisation and diagnostics of some Longidorus species (Nematoda: Longidoridae) from Russia and other countries using rRNA genes. European Journal of Plant Pathology, 138, 377-390. http://dx.doi.org/10.1007/s10658-013-0338-9

Tarjan, A.C. (1969) Variation within he Xiphinema americanum group (Nematoda: Longidoridae). Nematologica, 15, $241-252$. http://dx.doi.org/10.1163/187529269X00678

Taylor, C.A. \& Brown, D.J.F. (1997) Nematode-transmitted viruses. In: Lamberti, F., Taylor, C.E. \& Seinhorst, J.W. (Eds.), Nematode vectors of plant viruses. CAB International, Wallingford, pp. 142-143.

Trudgill, D.L., Brown, D.J.F. \& McNamara, D.G. (1983) Methods and criteria for assessing the transmission of plant viruses by longidorid nematodes. Revue de Nématologie, 6, 133-141.

Tzortzakakis, E.A., Archidona-Yuste, A., Cantalapiedra-Navarrete, C., Nasiou, E., Lazanaki, M.S., Kabourakis, E.M., Palomares-Rius, J.E. \& Castillo, P. (2014) Integrative diagnosis and molecular phylogeny of dagger and needle nematodes of olives and grapevines in the island of Crete, Greece, with description of Xiphinema cretense $\mathrm{n}$. sp. (Nematoda, Longidoridae). European Journal of Plant Pathology, 140, 563-590. http://dx.doi.org/10.1007/s10658-014-0488-4

Vieira, P., Mota, M., Padre, L. \& Adão, H. (2008) List of Nematodes (Nematoda). In: Borges, P.A.V.; Abreu, C., Cunha, R., Aguiar, A.M.F., Carvalho, P., Jardim, R., Melo, I., Oliveira, P., Sérgio, C., Serrano, A.R. \& Vieira, P. (Eds.), A list of the terrestrial fungi, flora and fauna of Madeira and Selvagens archipelagos. Direcção Regional do Ambiente da Madeira and Universidade dos Açores, Funchal and Angra do Heroísmo, Madeira, pp. 221-236.

Ye, W. \& Robbins, R.T. (2003) Longidorus grandis n. sp. and L. paralongicaudatus n. sp. (Nematoda: Longidoridae), Two parthenogenetic species from Arkansas. Journal of Nematology, 35, 375-387.

\section{Electronic supplementary material}

Additional Supporting Information may be found in the online version of this article at the publisher's web-site:

TABLE S1. Occurrence and distribution of Longidorus, Paralongidorus and Xiphinema species in Portugal. 